\title{
Dancing with Empty Water Bottles at L'Afrique a un incroyable talent, Brought to You by Nestlé
}

\author{
Marie-Anne Kohl \\ Research Institute for Music Theatre Studies, University of Bayreuth, \\ Bayreuth, Germany \\ marie-anne.kohl@uni-bayreuth.de
}

\begin{abstract}
Departing from a close reading of a particular performance to examplify localisation processes of the global Reality TV talent show format, this paper offers an analysis of the relationship between talent shows and patronage. Based on a concrete music and dance performance analysis, it further contributes to the more general discussion of transnational format trade and format adaptation by putting a focus on the entanglement of patronage, intervention and transformation. The analysis of the performance in question addresses how the musicians and dancers approached a concrete problem by creating a sense of belonging, involvement and disorientation through aesthetic means. With their critical stance, they position themselves in a specific local performing arts tradition, which itself is connected to earlier theatre and TV talent contests. Referring to the concept of glocalisation, I suggest that local topics of critique and intervention are part of the localising effect of the Reality TV talent show format.
\end{abstract}

\section{Keywords}

African talent shows - L'Afrique a un incroyable talent - Mbalax - Glocalisation - Critical Performance - Nestlé - Commodification of Art - Water Problem - Senegalese Dance 
In 2016, the global corporation Nescafé, a subsidiary of Nestlé, paired up with the production company Periscoop to create L'Afrique a un incroyable talentan adaptation of the successful series "Got Talent" for francophone West Africa, thereby suggesting that Nescafé would like to present itself as patron of young artists in the region. ${ }^{2}$ In the inaugural season, Senegalese dance troupe Séné Africa auditioned with an original piece that explicitly broached the issue of water shortage. This approach is clearly identified and lauded by the judges of the show; however, no connection was made between the topic of the performance and the water politics of the show's sponsor. The potentially interventionist or transformative character of the performance was not acknowledged. Rather, departing from aesthetic reasoning, the performers were asked by the jury to change certain aspects of the performance that were perceived as somewhat unprofessional and irritating.

In this paper, I analyse the performance in question, addressing how the musicians and dancers approached the issue of water shortage by creating a sense of belonging, involvement and disorientation through aesthetic means. With their critical stance, they position themselves in a specific Senegalese performing arts tradition, which itself is connected to earlier theatre and TV talent contests. Further, I argue that the very idea of intervention is actually part of the format of L'Afrique a un incroyable talent - critical positions are welcomed. Referring to the concept of glocalisation, I suggest that topics of critique and intervention are, in fact, localised. The "water problem", as one judge calls it, is a political issue specific to the local African context, in which L'Afrique a un incroyable talent takes place. It therefore adds to the localising effect of the show.

Departing from a close reading of this particular performance to examplify localisation processes of the global Reality TV talent show format, this paper offers an analysis of the relationship between talent shows and patronage. Based on a concrete music and dance performance analysis, it further contrib-

1 This article is a revised version of a paper presented at the international symposium "Power to the People? Patronage, Intervention and Transformation in African Performative Arts" at Moi University in Eldoret, Kenya, from March 20-25, 2018. For her research on "Castingshows als global gehandeltes Musiktheater," the author got funded by the German VolkswagenStiftung.

2 See, for example, Mauricio Alarcon, Country Manager for Nestlé Atlantic Cluster, on Nescafé's website in the article Nestlé, "Africa's Got Talent and Nescafé helps talented youth to get started," at www.nestle-cwa.com/en/media/pressreleases/africas-got-talent (retrieved July 26th 2018). 
utes to the more general discussion of transnational format trade and format adaptation by putting a focus on the entanglement of patronage, intervention and transformation.

\section{Setting the Scene}

\subsection{The Talent Show L' Afrique a un incroyable talent}

L'Afrique a un incroyable talent is a vaudeville talent show aired on international television channels, such as by Canal 2 International in Cameroon, ORTM in Mali, RTB in Burkina Faso, RTI in Côte d' Ivoire, TFM in Sénégal and the panAfrican A+ of Canal,$+{ }^{3}$ and featuring a variety of artistic and entertainment acts, such as acrobats, dancers, ventriloquists, magicians, impersonators and the like. The first episode of each season recounts the public, pre-produced auditions, during which contestants from various francophone West African countries try to convince the judges and the audience of their talent. In 2016, there was Vounoundougou Augustin from Cameroon who performed as Le Berger (The Shepherd). At first, the judges were confused as he took the stage dressed in traditional Fulbe garments producing animal sounds. He then surprised and enthused them with his elaborate rap that promotes love, peace and unity among all (African) peoples and religions. ${ }^{4}$ There was also Samuel from Gabon, whose rendition of Céline Dion's "The Power Of Love" received more than three million views on Facebook and was acknowledged (and approved) by the singer herself in the form of a comment on the video. However, at the L'Afrique a un incroyable talent auditions, Samuel didn't win the jury's approval, neither did Rebecca Atcha from Côte d'Ivoire with her interpretation of another Dion song, "Pour que tu m' aimes encore". But Senegalese dance company Séné Africa, who had toured with renowned mbalax ${ }^{5}$ artists Viviane

3 See Baudelaire Mieu, “'L'Afrique a un incroyable talent': à Abidjan, l'émission de téléréalité recherche ses pépites francophones," at www.jeunafrique.com/328323/culture/cote-divoire-a -abidjan-got-talent-recherche-talents-africains-francophones/ (retrieved July 26th 2018) and Suzika et al., "L' Afrique a un incroyable talent," at fr.wikipedia.prf/w/index.php?title=L\%27Af rique_a_un_incroyable_talent\&oldid $=153114743$ (retrieved October 16th 2018).

4 For information on the artist and the song see: Music In Africa Central Africa team \& Walter Badibanga, "Le Berger—Le son du Berger," at www.musicinafrica.net/node/15729 (retrieved July 26th 2018) or Atome, "Ecoutez 'le son du Berger': Message de paix et identité Culturelle," at voilamoi.over-blog.com/2016/o7ecoutez-le-son-du-berger-message-de-paix-et-identite-cult urelle.html (retrieved July 26th 2018).

5 Mbalax is a Senegalese style of music and dance that will be discussed in more detail later in this article. 
N'Dour and Pape Diouf, convinced the jury with a critical performance about water shortage.

During the auditions, the show's judges-Beninese singer and songwriter Angélique Kidjo, French-Ivorian actress and comedian Claudia Tagbo, and Congolese singer, dancer, composer and producer Fally Ipupa-evaluate the contestants and their performances. If they dislike a performance, they can press a red buzzer; if all of the judges press their buzzers, the performance ends immediately. After each audition the judges review the performance and vote on whether the respective contestant should remain in the competition. Following the pre-recorded public auditions are live episodes that take place in Abidjan, Côte d' Ivoire, where more contestants are eliminated every week. In the season finale, the jury chooses the winner of the show. In 2016, it was Le deux frères Sylla, an acrobatic duo from Conakry, Guinea. Additionally, the audience can vote via the internet upon a second prize: the "Nescafé winner". ${ }^{6}$ In 2016, the Nescafé winner was magician Thibaut Adotanou from Benin.

In this paper I discuss Séné Africa's performance for their L'Afrique a un incroyable talent audition during its inaugural season in 2016 in relation to the topics defined by this volume and the symposium on which it was based: patronage, intervention and transformation. Therefore, I connect the focus of my analysis to the following questions, posed by the outline of this volume: What are the economic conditions and socio-political contexts of L'Afrique a un incroyable talent, which was adapted from its popular "Got Talent" cousins? What kind of artistic intervention takes place? Who is the performer, who is the audience, and who is financing the performance? What are the effects as well as the goals of the donors' agendas, and how do they attempt to implement these agendas? By addressing these concrete contexts, this article contributes to a broader discussion of the relation between TV talent shows and patronage or sponsorship respectively.

\subsection{The Global Format}

Martin Nkosi Ndlela has pointed out the significance of acknowledging the entanglement of media-related economic positions-such as ownership or the conditions of production and global technological, political and socioeconomic transformations - with the proliferation of television formats in Africa. ${ }^{7}$ Asking about the economic and socio-political contexts of L'Afrique

6 See Nestlé, "Africa's Got Talent and Nescafé helps talented youth to get started".

7 Martin N. Ndlela, "The Political Economy of Television Formats in Africa: The Case of Big Brother and Idols," in New Patterns in Global Television Formats, ed. Karina Aveyard, Albert Moran, Pia M. Jensen \& Toby Miller (Bristol: Intellect Books Ltd, 2016): 217-230. 
a un incroyable talent thus necessitates a global perspective on the format of the television show itself, taking into account that the format is a globally traded media product. Along with other major talent show brands such as "Idol", "X Factor" and "The Voice", "Got Talent" belongs to a specific kind of Reality TV format that is increasingly dominating the global entertainment market; although they are conceived in the Global North, these shows are sold and adapted worldwide.

The "Got Talent" series was conceived by British media entrepreneur Simon Cowell and his company Syco Entertainment, which created, owned and sold the format as a media property together with what was then FremantleMedia, ${ }^{8}$ a subsidiary of the RTL Group and the largest television show producer worldwide. ${ }^{9}$ It was first realised as America's Got Talent in 2006, followed by Britain's Got Talent in 2007, and has since been adapted by a few dozen countries and transnational regions around the world, including South Africa's Got Talent in 2009, Arabs Got Talent in 2011, Nigeria's Got Talent in 2012, and L'Afrique a un incroyable talent in 2016. The latter is one of the most recent adaptations of the format, displaying the search for talent across francophone West African countries. ${ }^{10}$ The production and broadcasting rights for this version lie with the production company Persicoop, which partnered with Nescafé, a brand owned by Nestlé, ${ }^{11}$ who has sponsored talent shows before, but is also the world's largest transnational food and beverage company, as well as the world's largest pro-

8 In 2018, FremantleMedia became Freemantle Limited. See Sam Bradley, "Got Talent Producer Fremantle Media rebrands as Fremantle,” at www.thedrum.com/news/2018/og/o7/ got-talent-producer-fremantlemedia-rebrands-fremantle (retrieved October 16th 2018). See also Thomas Lückerath, "Fremantle feiert weltweiten 'Got Talent'-Erfolg," at www.dwdl .de/mipcom2012/37853/fremantle_feiert_weltweiten_got_talenterfolg_/ (retrieved October 16th 2018). FremantleMedia is today (as of 2018) Fremantle.

9 Timmy Ehegötz, Internationaler Lizenzhandel mit Fernsehformaten: Die programmpolitische Relevanz des TV Formathandels für deutsche Fernsehsender; analysiert an dem Formatimport "Ich bin ein Star — holt mich hier raus!" (Hamburg: tredition, 2015): 4.

10 Mateo Entertainment Group's website asserts that thousands of people went through a pre-casting in twenty-five francophone African countries. See Matthieu Lamarque, "L'Afrique a un incroyable talent—Episode 1-COMPLET," at chroniques.de.mateo.over -blog.org/2016/10/1-afrique-a-un-incroyable-talent-episode-1-complet.html (retrieved October 16th 2018). Nescafé sent a truck to several cities in Côte d' Ivoire, Burkina Faso, Mali, Senegal and Cameroon for the casting. See Nestlé, "Africa's Got Talent and Nescafé helps talented youth to get started". The current website states that for 2019 candidates from around the world can apply. See Nestlé, "L' Afrique a un incroyable talent," at www .tontalent.com/ (retrieved January 21st 2019).

11 See Nestlé, "Africa's Got Talent and Nescafé helps talented youth to get started", or Baudelaire Mieu, "'L'Afrique a un incroyable talent'”. 
ducer of bottled water. ${ }^{12}$ Making known the complex entanglement between a media format and corporate involvement is relevant when asking about showrelated financing, potential agendas and the role of patronage.

\section{3}

\section{Framing the Scene}

\subsection{The Glocal Format}

Recent studies within the growing body of transnational media research on global television formats emphasise the importance of adaptation and localisation in order for each regional version of the show to be successful. ${ }^{13}$ To create something that is identifiable for a local audience, different (albeit rather obvious) aspects of the show such as the language, content (e.g. the type of music performed) and personnel (e.g. the members of the jury) ${ }^{14}$ are adapted, as well as more complex facets, such as the emotional repertoire ${ }^{15}$ (e.g. the display of joy or tearfullness.) For L'Afrique a un incroyable talent, one specific change has been the role of the audience: in many versions of "Got Talent", the audience plays a crucial role by voting for their favourite candidates during the live shows via text messages, leaving the judges with only the role of commenting and counselling. In the francophone African format, the judges choose

12 Nestlé subsidiaries have previously sponsored "Britain's Got Talent" and "Pop Idol", among others. See Mark Kleinman, "Nestlé agrees £6m ITv Pop Idol deal," Marketing (January 3 oth 2003) and Alex Farber, "ITV works with Nestlé brand on digital strategy for talent show," New Media Age (May 3rd 2007): 9.

13 See for example the anthologies by Koos Zwan \& Joost de Bruin, Adapting Idols: Authenticity, Identity and Performance in a Global Television Format (Farnham: Ashgate, 2012) or by Karina Aveyard, Albert Moran, Pia M. Jensen \& Toby Miller, New Patterns in Global Television Formats (Bristol: Intellect Books Ltd, 2016), or by Andrea Esser, Iain R. Smith \& Miguel A. Bernal-Merino, Media across borders. Localising TV, film and video games (Basingstoke, New York: Routledge, Taylor \& Francis Ltd, 2016).

14 See Paolo Sigismondi, The Digital Glocalization of Entertainment: New Paradigms in the 21st Century Global Mediascape (New York, NY: Springer Science+Business Media LCC, 2011), or Andrea Esser, "European Television Programming: Exemplifying and Theorizing Glocalization in the Media," in Europe in a Global Context, European Glocalization in Global Context, ed. Roland Robertson (Basingstoke: Palgrave Macmillan 2014): 82-102.

15 See Laura Sūna, "Negotiating Belonging as Cultural Proximity in the Process of Adapting Global Reality Tv Formats," Media and Communication 6.3 (2018): 30-39. For more about the role of emotional display at talent shows, see Charles Fairchild, "Building the Authentic Celebrity: The 'Idol' Phenomenon in the Attention Economy," Popular Music and Society 30.3 (2007) and Yuanchen Zhang, "How Culture Influences Emotion Display in Transnational Television Formats: The Case of The Voice of China," Media and Communication 6.3 (2018): 40-47. 
the winner, although the additional Nescafé winner is selected by the audience who can vote online. These contexts suggest that $L^{\prime}$ Afrique a un incroyable talent can be understood both globally and locally at the same time. It is global because its structure and format are recognised worldwide, yet it is specifically West African and accessible to a local audience because West African artists fill the line-up, perform their art, and are evaluated by a West African jury. Global formatting and local adaptation are hence closely interrelated. Therefore I would like to reference these processes in relation to the concept of "glocalisation", a term coined by sociologist Roland Robertson in the early 199os in order to point out the interdependency of the global and the local. ${ }^{16}$ More importantly, author Max A. Smith writes: "Effectively, the concept of 'glocalization' recognizes the agency of individuals at the local level and their ability to redefine the field in which outside influence can enrich their culture and economy."17 Acknowledging the agency in appropriation is a relevant point of reference for considering questions about intervention and transformation.

While research on appropriation in the context of media and popular culture in Africa has been extensive since the early $1990{ }^{18}{ }^{18}$ research specifically on African talent show adaptations is still rare and emerging, ${ }^{19}$ but its presence alone indicates a recent shift in transnational media studies from focussing on Western adaptations to including perspectives on and from the Global South. ${ }^{20}$ Although frequent critiques on the neoliberal qualities of talent shows could easily be grounded in a musicological point of view (which argues that the

16 Roland Robertson, "Glokalisierung. Homogenität und Heterogenität in Raum und Zeit," in Edition zweite Moderne. Perspektiven der Weltgesellschaft, ed. Ulrich Beck (Frankfurt am Main: Suhrkamp, 1998): 192-220, and Roland Robertson, Europe in a Global Context, European Glocalization in Global Context (Basingstoke: Palgrave Macmillan, 2014).

17 Max A. Smith, The 'Glocalization' of Mobile Telephony in West and Central Africa. Consumer Appropriation and Corporate Acculturation: A Case Study in Cameroon and GuineaConakry (Oxford: Langaa RPCIG, 2018): 8.

18 See Karin Barber, New Approaches to African History, vol. 11, A History of African Popular Culture (Cambridge, U K and New York, NY: Cambridge University Press, 2018): 13 off.

19 See, for example, Martin N. Ndlela, "Global Television Formats in Africa: Localizing Idol," in Global television formats: Understanding television across borders, ed. Tasha G. Oren \& Sharon Shahaf (Now York, NY: Routledge, 2012): 242-259; or Tess Conner, “'Accept no Limitations': Expressions of Diasporic Identity in Nigerian Idol," in Adapting Idols: Authenticity, Identity and Performance in a Global Television Format, ed. Koos Zwan \& Joost de Bruin (Farnham: Ashgate, 2012): 69-8o; or Tess Conner, "Global Reality Television and the Concept of Recursion: Idols in African Contexts," in New Patterns in Global Television Formats, ed. Karina Aveyard, Albert Moran, Pia M. Jensen \& Toby Miller (Bristol: Intellect Books Ltd, 2016): 231-244.

Koos Zwan \& Joost de Bruin, “Introduction," in Adapting Idols (2012). 
shows' raisons d'être are reactions to the crisis of the music industry in general), ${ }^{21}$ explicitly musicologist approaches to this television show format are still marginal. ${ }^{22}$ However, I suggest that a musicological, performance-centred perspective allows for a more detailed and specific analysis of the show's impact in regard to the aforementioned questions. I will thus focus on a close reading (or 'close viewing' and 'close listening'), in the sense of a detailed observation and interpretation, of a single performance during L'Afrique a un incroyable talent in 2016. Before discussing the example, I will frame the conceptual points of reference: performance and the role of patronage, intervention and transformation.

\subsection{Performance: Patronage, Intervention, Transformation}

In Séné Africa's performance at L'Afrique a un incroyable talent, aspects of patronage, intervention and transformation seem to go hand in hand. It is the entanglement of these aspects that interest me in this analysis.

My rather broad understanding of patronage in the arts, as the sponsoring of artists and their work primarily through financial support, implies the notion that donors have an agenda that goes beyond their interest in the art itself. These interests - sometimes more transparent than others-might be the revaluation of their own public image, as for example often seen in the relationship between the patron and the griot(te); or the exertion of influence on social and/or political processes and public opinions with the aim of using art as a means of transformation, exemplified by NGO s sponsoring local intervention theatre groups. When it comes to the latter, literature and drama professor Christopher Odhiambo has pointed out the paradoxical condition between patronage as a necessity for its very (financial) viability and the potential compromise of the artists' enterprise. ${ }^{23}$ Looking at L'Afrique a un incroybale talent, this paradox is somewhat comparable. On the one hand, the real and undeni-

21 Charles Fairchild, Pop Idols and Pirates: Mechanisms of Consumption and the Global Circulation of Popular Music (Aldershot: Ashgate, 2008).

22 See, for example, Katherine Meizel, Idolized. Music, Media, and Identity in American Idol (Bloomington: Indiana University Press, 2011); Stijn Reijnders, Gerard Rooijakkers \& Liesbet van Zoones, "Community Spirit and Competition in Idols: Ritual Meanings of a TV Talent Quest," European Journal of Communication 22.3 (2007): 275-292; or Stephen Graham, "The X Factor and reality television: beyond good and evil," Popular Music 36.1 (2017): 6-20; or contributions in Dietrich Helms \& Thomas Phleps, Populäre Musik im Wettbewerb (Bielefeld: transcript Verlag, 2005).

23 See Christopher J. Odhiambo, "Intervention Theatre Traditions in East Africa and the Paradox of Patronage," in Rethinking African literary and intellectual landscapes, ed. James Ogude, Grace A. Musilam \& Dina Ligaga (Trenton, NJ: Africa World Press, 2012): 55-72. 
able chance for artists to increase their public profiles as well as possibly to win the grand prize of ten million CFA francs only exist because the show does too. On the other hand, artistic freedom is compromised as the performances need to match the show's formal requirements, some specific content might be externally predetermined or censored a priori, and the participants must hand over most of their rights to the producers. Additionally, the show's economic interests challenge the idea that sponsorship of the arts is really what it is all about - and with the obvious profit-oriented nature of the format in mind, it is more than fair to talk about patronage in the context of talent shows. However, the relations between the producers of the show and its participants only reveal the asymmetrical power dynamics that are intrinsic to the very idea of patronage itself. As previously discussed, the aim to redefine one's own image can also be an inherent part of patronage. The narrative of the show and its sponsors corresponds to this notion in that it purports to only wanting to discover, support and promote new talent. The show, its sponsors and producers thus construct their own image as that of a patron.

Considering the ideas of intervention and transformation might further complicate the asymmetrical relationship between patron and artist. Intervention can be used as a tool by the authorities, affecting artistic freedom by repression or sponsorship, ${ }^{24}$ or using interventionist artistic forms to directly promote their own agenda. But intervention in the arts can also be understood-in the sense of "classical" interventional art forms such as public, street and performance art, or interventional theatre - as an attempt to intervene effectively against authorities with the goal of disrupting and changing a status quo. It is the latter understanding that interests me when looking at performances from L'Afrique a un incroyable talent.

Intervention implies the desire for change, for transformation. But what kind of room can there be for interventionist, transformative action within the realm of a talent show that is thoroughly formatted, structured and monitored? The show, in line with its image as a patron, is focussed on promoting young talent with the potential to transform their lives and careers, yet it seems as if the sponsors are not interested in the transformative power of art itself. Despite this, I would like to draw on the concept of performativity ${ }^{25}$ in order to under-

24 See Karin Barber, "Popular Arts in Africa," African Studies Review 30.3 (1987): 33.

25 With regards to gender or theatre as performance, the concept of performativity has been established by theorists such as Judith Butler and Erika Fischer-Lichte in order to stress the processuality of realities and of doing things, and the constructive power of these processes to generate precisely these realities and things by doing, by performing them. See, for example, Judith Butler, "Performative Acts and Gender Constitution: An Essay 
stand artistic performances as social and aesthetic acts that do not merely represent predetermined conditions - be it related to gender, ethnic or cultural identity, a musical genre, or a specific social issue. Rather, in terms of performativity, artistic performances can also (de-)construct and transform these very conditions. While these processes indicate that conditions are not deterministic, they are also not necessarily performed voluntarily. I am therefore interested in the ways in which the participants of L'Afrique a un incroyable talent appropriate the talent show format through their performances' performative potentials to (de-)construct and transform, be it voluntarily and intentionally or not. In this article my understanding of transformation focusses on aesthetic transformations as well as the transformations of a status quo that result from an intervention, exemplified by Séné Africa's performance.

\section{4 The Scene}

Séné Africa's audition for L'Afrique a un incroyable talent was shown on television and later on YouTube ${ }^{26}$ through a short sequence of vignettes, including some clips of the group joking around with the moderators Daouda Sane and Konnie Touré, dancing backstage, and giving a short interview about their history. When taking the stage, the group introduced themselves to the judges as Séné Africa from Senegal, a dance, music and percussion company that has been performing together since their youth. Before starting the performance, they split into two groups: Two musicians sat on stage right and a third one re-entered the stage from the left with a tama (talking drum). At the centre of the stage, five dancers embraced with their heads together and started to turn in unison. One musician began by playing the tama while the dancers moved around in a tableau-like arrangement, each person holding an empty plastic water bottle. The five performers stared at and lifted their bottles as if they were desperately, unsuccessfully attempting to drain the tiniest remaining drops of water into their mouths. The spectacle culminated in the crushing and re-inflation of the bottles, obviously producing the associated sounds, which were rhythmised and induced a transition from the theatrical tableau into mbalax dance moves, performed mostly in unison. The handling of the

in Phenomenology and Feminist Theory," Theatre Journal 40.4 (1988): 519-531; or Erika Fischer-Lichte, Performativität: Eine Einführung (Bielefeld: transcript Verlag, 2016). 
bottles continued to serve as a rhythmic track, initially in synch with the tama and later accompanied by an elaborate set on the sabar drum and the keyboard, which increased the tempo. At one point all of the dancers fell simultaneously to the ground. The music calmed down and changed from rhythmic patterns to descending, sustained notes. The dancers then got back up, once more moving in unison, calling on each other, in Wolof, to turn around. After a few turns together, they again began to perform individualised jerking movements, emphasised by the sabar, with some of them returning to their empty bottles. They ended the performance with an upward note played by the keyboardist and a crush of the plastic bottles in another tableau-like arrangement, one of the dancers holding the other performers at arm's length with his bottle raised to his lips.

Overall, the judges' reaction was very positive: they complimented the performance, the group's coherence, their style, their look, and they also positively noted that there is a woman in the group, even though it's only one. However, Kidjo and Tagbo criticised the pianist, literally speaking of the "wrong notes" he played, and suggested that the keyboard be removed. Indeed, the keyboarder's playing seemed arbitrary and negligent, almost even careless, and didn't quite fit with the professionalism of the percussion and dance performance. The keyboard part comes across as inapt and even rather disturbing.

While the inclusion of live piano derives from the common mbalax instrumentation, I want to suggest that its specific effect in this performance is pivotal for the performance's message to be conveyed. Whether this effect was intentional or not is not crucial to understanding its potential impact. Even if not intended, the discomfort produced by that part of the soundtrack-properly reflected in the two judges' reaction-corresponds with the meaning of the dance. Something is not right, something is out of balance. Séné Africa's performance, in my understanding, has a clear topic linked to a message: the water shortage and its critique. Why did they address this problem in a context like L'Afrique a un incroyable talent? On the one hand, there is the potential impact of such a critical performance that addresses one of the most urgent social, geopolitical problems of our time - globally and locally — when staged on such a wide-reaching platform; there is a considerably large audience that can be reached, if it should be the intention of Séné Africa to raise awareness and transform public recognition of the issue. While the necessity of raising awareness for a problem that the majority of the audience is likely already aware of can be doubted, it is exactly the very idea of artistic critique that situates their performance in the tradition of Senegalese theatre and TV talent contests, as I demonstrate in the next but one sub-section. On the other hand, I suggest that giving this performance within the context of L'Afrique a un incroyable 
talent, whose biggest sponsor is Nescafé, and by extension Nestlé, is what made for the real critical moment.

The critical message of Séné Africa's performance was not missed by the jury. Kidjo remarks that one thing she likes about the performance is its "comment on the water problem". What struck me was that, while praising the group's critical approach, she is seen at the judges' table with a Nescafé cup in front of her. In the following, I would like to point out the paradox of this situation and contextualise the performance of the Senegalese group.

\subsection{Mbalax as Mode of Expression}

In their performance, Séné Africa assembled theatrical elements and mbalax dance. As a popular music genre, mbalax was formed in Senegal in the early 1980 s within the context of significant musical, technical and socio-political transformations. ${ }^{27}$ When sabar and tama drums and rhythms were introduced into contemporary Afro-Cuban- and Latin-American-inspired popular music, it led to the development of a distinct style. The instrumentation of the mbalax band reflected "traditional sabar ensembles adapted for modern instruments". ${ }^{28}$ The keyboard, for example, is a permanent feature in mbalax, and adopts a highly syncopated, percussive position (159), consistent with its use in Séné Africa's performance. In the early days, mbalax became pervasive mainly through live mbalax bands that played in nightclubs throughout Dakar, deploying its own system of patronage (159). Mbalax soon became the epitome of Senegalese music, close to a "national symbol" (160), although its cultural grounding and roots are very specific, namely in Wolof culture. Hélène Neveu Kringelbach locates this fact within the "transition period from a panAfrican outlook to a re-centring on national interests" and deduces that "those cultural forms that promoted Wolof culture were favoured". ${ }^{29}$ Mbalax quickly became Senegal's “most important commercial export" (160), which challenged musicians to adapt their music - the codified polyrhythms of which made it

27 See Anja Brunner, Die Anfänge des Mbalax: Zur Entstehung einer senegalesischen Popularmusik (Wien: Inst. Für Musikwiss., 2010): 130.

28 Patricia Tang, African Soundscapes, Master of the Sabar: Wolof Griot Percussionists of Senegal (Philadelphia, PA:Temple University Press, 2007): 157. Further page references are in the main text.

29 Hélène Neveu Kringelbach, Dance Circles: Movement, Morality and Self Fashioning in Urban Senegal (New York, NY: Berghahn Books, 2013): 100. Further page references are in the main text. 
difficult for untrained ears to access ${ }^{30}$ — for Western audiences "without compromising its integrity", ${ }^{31}$ partially resulting in two different versions of mbalax: one for home and one for the global market. "From the outset [...] the success of mbalax was based on the musicians' capacity to adapt the genre to seduce the Senegalese youth as well as African music-lovers abroad."32 Mbalax presents itself as open to transformations, itself a glocal genre.

No matter where it is heard, mbalax is dance music. According to Patricia Tang, the "basic style of mbalax dance involves carefully nuanced pelvic gyrations and knee movements" and occasionally a "more traditional sabar dance style, with elegant jumps and flailing limb movements". ${ }^{33}$ However, the dance style is subject to permanent change, and "new dance crazes are constantly emerging" (159). Since the 199os, mbalax has become increasingly disseminated through television, and local audiences - regardless of their age, gender or religious identity-have copied the new choreographies at home and used them as the basis for further improvisation. Eleni Bizas therefore sees mbalax videos as an important reference point for the circulation and transformation of dance movements in Dakar. ${ }^{34}$

The lyrics of mbalax songs, sung primarily in Wolof, are extremely important for the audience. Although mbalax singers occasionally continue the griot tradition in praising patrons, the more dominant mbalax lyrics are of a sociopolitical nature, often addressing social, religious, familial and moral topics, to name just a few. ${ }^{35}$ Given this information, it is striking that Séné Africa did not include singing in their performance. While lyrics can explicitly address a problem, Séné Africa chose to use aesthetic means to formulate their critique, relying on theatrical props, pantomime and tableaus to tell their story. By doing so, they could make their point without having to call a spade a spade. Should they have intended to directly criticise Nestlé, this approach provided a way in which they could target the company without explicitly attacking the patron. Dancing with empty water bottles at L'Afrique a un incroyable talent acted out the critique normally performed by words.

\footnotetext{
$30 \quad$ Kringelbach, Dance Circles, 100.

31 Tang, African Soundscapes, Master of the Sabar, 16o.

32 Kringelbach, Dance Circles, 100.

33 Tang, African Soundscapes, Master of the Sabar, 159. Further page references are in the main text.

34 See Eleni Bizas, Learning Senegalese Sabar: Dancers and Embodiment in New York and Dakar (New York, NY: Berghahn Books, 2014): $193 \mathrm{f}$.

35 See Tang, African Soundscapes, Master of the Sabar, 159.
} 


\subsection{A History of Performance as Form of Critique}

The integration of everyday experience, social engagement and a critical stance towards authorities into the work of musicians, of theatre and performance groups have a specific history in Senegal, Séné Africa's home, and its youth culture. So does the practice of producing for and performing these pieces in the context of theatre and TV competitions. These movements have always been accompanied by attempts to exert influence on the part of single politicians and state institutions. Far from being a univocal relation of resistance versus appropriation, the cultural agents' position towards the political regime was one between opposition and arrangement. ${ }^{36}$ Susann Baller argues with Achille Mbembe that in this regard the relationship between the critical youths' and performing arts movements, on the one side, and the political state regime, on the other side, can be characterized as the ambivalent simultaneousness of conviviality and connivance (29).

Baller registers orchestrated theatre competitions in Senegal as early as in the 1950s, then still organised by colonial administration under the patronage of its "Associations Centres Culturels" (290). Around the same time, popular theatre started to emerge. Being engaged in performing theatre was, besides playing football, a favourite pastime for students during their holidays (293). After independence, the Senghor administration established the national theatre "théâtre national Daniel Sorano" with ballet, music and theatre companies in 1965 (290). However, parallel to these state-funded structures, also "popular theatre" grew more and more popular, often in form of satires. Today there are local theatre groups in almost every small town in Senegal, that are also socially committed (302). But already back in the 196os, local theatre engaged in the "education of the masses", with topics that not only focused on pre-colonial times, but often on current issues that reflected the everyday life of the theatre makers and their audiences $(291,293)$.

While the Senegalese government was suspicious of the many local theatre groups, it also saw the potential of using them for its own agenda to educate the Senegalese citizen, to preserve and revalue cultural heritage and propagate African culture and theatre. Therefore, in the mid 196os the ministry of youth and sport founded different theatre federations in an attempt to control their activities (292 ff.). This lead to a first big festival with a nationwide competition for popular theatre in 1975, organized by the "Fédération nationale du théâtre et de la musique populaire", who back then had a membership of

$3^{6}$ See Susann Baller, Spielfelder der Stadt. Fußball und Jugendpolitik im Senegal seit 1950 (Köln, Wien: Böhlau, 2010): 138. 
almost 200 theatre groups with more than 6000 actors. The festival represented the immense diversity of popular theatre of the time (294). It also reactivated a debate about the function of popular theatre in Senegal between advocating choral singing, acting, and poems, and bridging the gap between audience and theatre, sensitizing the audience for the economic development of their country, and addressing the problems of everyday life and contributing to their solutions (296).

In the 1970s, popular theatre found a strong base in the so called "association sportive et culturelle" (ASC), which provided spaces for sportive, social and cultural activities, as well as, early on, a refugium to dissidents $(137,290 \mathrm{f}$.) The ASC evolved in the 1970s from the "navétanes" football teams and associations and the so called "clubs yé-yé". While state officials claim that they had seen the potential in the popular navétanes and yéyé clubs, which they monitored warily, and transformed them into the new structure through which they could govern, organize and depoliticise the youth, representatives of the associations themselves understand the ASC to be their own initiative, established partly even in opposition to the regime $(138,141 \mathrm{f}$.).

The clubs yé-yé had been small associations which shaped everday life and cultural imagination of Senegal's, mainly male, youths of the 196os and 1970s (88). They picked up manifold transnational influences in music, fashion, and dance. Their reference of a plurality of styles had a political dimension, as Baller indicates with reference to Ibrahima Thioub and Ndiouga Adrien Benga, as it represented an alternative to the national commemorative culture of unity (92). Although being informal, the members and their clubs, who understood themselves as being truly democratic and modern, were organized extraordinary strictly $(101,112)$, which made them the perfect precursors of the ASC.

The clubs navétanes ${ }^{37}$ were local football teams of young students, that were first founded in Senegalese cities in the 1950s. Football is extremely popular in Senegal, and has been so for decades. The clubs navétanes organised local tournaments during school holidays in the rainy season (15f.). Therefore the name. The quantity of these teams and tournaments constantly grew in the 1960s, so that the Senegalese ministry for youth and sport tried to gain influence within the clubs navétanes, and founded the "organisme national de coordination des vacances" (ONCAV) in the early 1970s to organise annual tournaments (16). However, over time the clubs themselves took over the control of ONCAV, and the ministry lost control over the tournaments. Further, the clubs diversi- 
fied their activities and tournaments beyond football into other sports and the realms of theatre and social engagement, and gave the clubs their new denomination: ASC (16.). The "C" for "culturelle" in ASC refers to diverse activities, such as theatre, puzzle games, holiday and alphabetization courses, the collection of books and the installation of libraries, painting competitions and beauty pageants, social projects, vaccination campaigns and so forth (289).

Baller suggests that the strengthening of the clubs navétanes and their transformation into ASC were based on the closing of the universities as reaction to the 1968 student protests, when the youths returned to and wanted to get engaged in their quarters. Many of them were closely associated with banned opposition parties. Thus, the associations also became a refugium to youths that were critical of the regime $(143,154)$. It was them who also brought the interest for culture to the ASC (143).

By the end of the 1970s, theatre and music competitions were equally important activities as football matches, and eventually became even mandatory for the ASC (298). More and more theatre groups were founded in the realm of the ASc. Founding members of theatre groups in Pikine and Guédiawaye stressed their intention to pick up topics from their social environment and to point out specific problems to the audience. Their topics were current, sociocritical, and sometimes provocative (299 f.). In this realm, popular theatre of the 1970 and early 1980 os was perceived as being politicized, critical of the regime and frankly critical of imperialism and neo-colonialism. (300) This was based on the chosen topics which addressed the conditions in the city quarters. One example explicitly broached the problem of the lack of drinking water. (300 f.) This is only one parallel to the performance of Séné Africa at $L^{\prime} A$ frique a un incroyable talent decades later. The Asc theatre competitions had a very strict structure, a jury and a very distinct evaluation scheme (307); specifications that were often seen as too limiting and controlling by members of the Asc. Aesthetically and topically, the competitions were oriented on traditional national heritage and on the principle of "théatre total" as a unit with choir, folklore, theatre and poem (304). The typical performance would be performed in Wolof and include dance and music (300). Séné Africa's idiosyncratic mixture of mbalax, tableau, life music and short Wolof calls seems reminiscent of these outlines. Today, ASCs are omnipresent. ${ }^{38}$ Baller extensively investigated several ASCs in the cities of Pikine/Guédiawaye, where also Séné Africa was

38 Baller, Spielfelder der Stadt, 149. In the 1990s there were 372 ASC in the region of Dakar alone, in 2004 there were, statewide, 2,300 ASC with 300,ooo members registered (Baller, Spielfelder der Stadt, 137). 
based, more specifically at the Centre Polyvalent de Thiaroye Gare. ${ }^{39}$ Thiaroye, a neighborhood of Pikine/Guédiawaye, is according to Baller one of the most difficult social environments in Senegal and has been, since the 199os, home to cultural activists such as several hip hop and rap formations who criticized the social problems in their home quarters $(287 \mathrm{f}$.). It seems coherent to also see Séné Africa's critical performance at L'Afrique a un incroyable talent in the context of this history.

Despite the socio-political layout of some of the Asc activities, the legal premises require them to be unpolitical. Integrating the idea of the unpolitical into the ASC self-image helped again and again, over the decades, to ward off political influence from the side of state officials, but also helped single politicians to stage themselves through donations to the ASC as unpolitically generous (154f.). The relation between the ASC and state is complicated and ambivalent, between aforementioned convivality and connivance (29). The importance of theatre groups started to become marginalized, when they started to understand themselves mainly as agents of social projects in cooperation with local NGO s, reminiscent of theatre of development. The criticism of local problems raised in plays today hardly seems provocative any more $(291,309)$. Baller suggests that it might be precisely the verdict of the "apolitical" that now renders it impossible that the theatre groups of the Asc be a political mouthpiece for young people, but rather makes them, if at all, a cooperation partner for non-governmental organizations (309). More critical plays today would rather occur elsewhere than within the compulsive programs of ASC competitions (314).

Starting in 1993, a new and immediately hugely popular TV show called "Oscars des Vacances" co-opted the performing groups of the ASC..$^{40}$ Its focus, however, was and is less on theatre performances than on mbalax dance styles (103). Yet, the competition also encompasses a short play which often treats social issues, a beauty pageant, and a quiz on the "state's achievements in various development-related fields" (105). The show "Oscars des Vacances" runs annually between July and September, in the middle of the rainy season, during school holidays, similar to the ASC contests and tournaments. The TV competition was established by the former football player Aziz Samb (104). The continuing entanglement of football and the arts in Senegal is intriguing. And Kringelbach states that today mbalax videos are "as popular as football and

39 See title and comments at www.youtube.com/watch?v=HcPjgZGHerQ, retrieved February 2oth, 2020. Unfortunately, I was unable to establish contact with Séné Africa personally, thus my information on the dance group is based on online investigation. 
Latin American soap operas" (103). Samb had previously, in the 1980s, been active in variety TV in Côte d' Ivoire, whose biggest city Abidjan back then was a "centre of musical production in West Africa", (104) and is today the media hub from where L'Afrique a un incroyable talent is aired. The Oscars had first been aired on the Senegalese TV station RTS, and since 2007 by the privately-owned channel $2 \mathrm{~S}$ TV. It had started out in a small theatre in Dakar but soon moved to a basketball stadium (104).

Kringelbach points out that "the Oscars" were created as an attempt to occupy the youth during the school holidays and can be understood as "another facet of the state's attempt to control youthful energies and to shape the moral domain." (104). Also corporate involvement had incrementally shaped the competitions at the Oscars through sponsorship, advertising, cash prizes and job opportunities (cf. 105). Not only these contexts are interestingly reminiscent of L'Afrique a un incroyable talent. Also the composition of the Oscars' jury which is "made up of well-known figures in the Senegalese musical and artistic world [...], state officials and representatives from the corporate sponsors" (105) offers a reference point. Although the histories of the two competitions are not related and only one of them can be really understood as locally anchored and grown, by means of "the Oscars" the Senegalese audience was well prepared to receive a format such as L'Afrique a un incroyable talent as yet another local, relatable talent contest. It is also an example for how corporate sponsorship and patronage have been implemented in francophone African media and performance art contexts for about three decades.

The performance of Séné Africa and its critical stance can therefore be seen within these historical contexts. They can be understood as a continuation of a tradition in using theatrical means for a critical positioning and broaching issues of social relevance such as shortage of drinking water, also within the realm of theatre competitions, as well as performing mbalax with similar objectives in the realm of a TV competition.

\subsection{Nestlé as Patron}

Besides framing Séné Africa's performance within the historical context of theatre and TV competitions in Senegal, I would like to suggest a further line of interpretation for reading the performance as potential intervention.

As the world's largest producer of bottled water, Nestlé has repeatedly been criticised for its involvement in the privatisation, extraction and distribution of drinking water and its aggressive water politics. ${ }^{41}$ Around the world and espe-

41 Critical voices are manifold. The main points of criticism are summarised by the Swiss 
cially in developing areas, the company is buying the right to extract natural water resources from local authorities, often cutting off the local water supply. Nestlé's role is controversial, with public voices that also promote the company's involvement. ${ }^{42}$ Parallel to this, Nestlé presents itself as benefactor and emphasises its social and educational engagement, for example as a supporter of the NGO Water Education for Teachers. In its own report from 2006, Nestlé proudly stated that "Only 49 of the 481 Nestlé factories lie in regions that are considered arid. They are in 13 of the 45-according to the water poverty index WPI of the World Water Council—classified as water poor countries." ${ }^{43}$ There are factories in Senegal, Guinea and Côte d'Ivoire - countries that participate in L'Afrique a un incroyable talent. The group whose performance is under analysis is from Senegal, and the competition was taking place in Abidjan, Côte d' Ivoire. A connection could be drawn between the performed critique and the show's sponsor. However, nobody drew this connection-not the judges nor the audience nor the moderators. This could raise questions about the public's understanding of Nestlés role in "the water issue". Additionally, the members of Séné Africa did not literally address Nestlé, so I cannot presume that they had drawn the connection and actually wanted to attack the company directly. However, in terms of performativity, intentionality is not a requirement for the effects and effectivity of a performance.

Nestlés image as a benefactor or sponsor dives into realms other than that of water, as is the case with L'Afrique a un incroyable talent:

We believe in people's dreams and think that everybody deserves to express their talent and get started [...] Nescafé's partnership with Periscoop and Africa's Got Talent is part of our brand's ongoing commitment to

documentary Bottled Water by Urs Schneller and Res Gehriger released in 2012. See Schneller \& Gehriger, "Ten things you should know," at www.bottledlifefilm.com/about -the-film\#1othings (retrieved April 4th, 2020).

42 See, for example, former Secretary General of the United Nations Kofi Annan speaking at the Nestlé Forum in Abidjan, Côte d' Ivoire, in June 2016 - the same time when auditions for L'Afrique a un incroyable talent were being held and a few months before the episodes were aired. At the Forum, he promoted the necessity of incorporating the corporate sector in the privatisation of water. See Kofi Annan Foundation, "Building Stronger Economies and Communities in Africa," at www.kofiannanfoundation.org/speeches/building -communities-africa/ (retrieved October 16th 2018) or Nestlé, "Creating Shared Value Global Forum 2016," at www.nestle.com/media/mediaeventscalendar/allevents/creating -shared-value-forum-2016 (retrieved October 16th 2018).

43 See Nestlé SA, Der Nestlé-Bericht zum Wassermanagement (Vervey: Nestlé, 2007): 31. Emphasis and translation my own. 
empower and inspire Africans from all over the region, especially young people, whether they are showcasing their talent or taking part by watching the show. This is their moment. ${ }^{44}$

Nescafé creates its image as a patron of young talent in West Africa. Moreover, through its overarching presence during L'Afrique a un incroyable talent and specific support of the Nescafé winner, it is the sponsor and patron of the show. The critical question remains how the patron can be effectively criticised, as Séné Africa's artistic comment on "the water problem" implicitly does.

\section{Interpreting and Closing the Scene}

Here I finally return to my question of the extent to which a performance and critique like that of Séné Africa can actually be understood as interventional, or even transformational. I would like to propose two concluding hypotheses.

\subsection{Aesthetic Interpretation}

In their performance, Séné Africa combine theatre and mbalax, introducing experimental keyboard elements, in an idiosyncratic way. Their fusion brings along aesthetic transformations. While transformation is common to mbalax, so much so that Séné Africa's aesthetic innovations could be understood as inherently stylistic, the group introduces a significant transformation, a savvy twist to mbalax concept: They pour its prevalent critical stance that is usually communicated through lyrics into an alternative mode of expression, from their voices into their bodies, made possible through their combination of mbalax dance with the theatrical props, pantomime and tableau. As a Senegalese group performing mbalax, the musical "national symbol," it can be argued that they were included in L'Afrique a un incroyable talent in order to represent Senegalese culture in a show that makes a point to transnationally embody francophone West Africa. By appropriating the glocal style that is home to their home, Séné Africa simultaneously appropriated the stage and the format of the talent show not only as their platform, but also as their facilitator for transformation. But is this performance likewise an intervention as well?

44 Mauricio Alarcon quoted as "Country Manager for Nestlé Atlantic Cluster" on Nescafé's website, see Nestlé, "Africa's Got Talent and Nescafé helps talented youth to get started". 


\subsection{Socio-political Interpretation}

Séné Africa was invited to the show, they did what they planned to do, they didn't disturb or interfere with the course of L'Afrique a un incroyable talent. Similar to the contexts of the Senegalese ASC theatre competitions and to the Oscars des Vacances, the group raised and performed their critique of social issues. Their performance was no intervention. However, there is an interventionist quality to their performance as they brought their critique into the show's format and established system. This protest did not happen outside on the streets, but inside the very sphere that is co-produced by the protagonist who is also partially responsible for the situation being critiqued. In this way, the performers appropriated the frame of the talent show for their own purpose and transformed it into a platform to disseminate their message. However, it is questionable if this can actually transform the patron's water politics, or the way talent show systems operate. My suggestion is rather that the very idea of intervention itself is already a part of the talent show format. Critical positions are welcomed. In terms of glocalisation, the local topics of critique may vary. The "water problem", again as Kidjo calls it, is a political issue specific (of course not only but especially) to the local context of L'Afrique a un incroyable talent. The very essence of the critical performance can therefore be seen as being part of the localising process that makes talent shows as successful as they are, and interventional aspects are already implemented and inscribed within the format. An effective critique - a prospective transformation even-is hence unimaginable, since the very idea of the critique is immediately subsumed by the format.

\section{Acknowledgements}

My gratitude goes to my dear colleagues Prof. Christopher J. Odhiambo, Dr. Samuel Ndogo and Dr. Ricarda de Haas, with whom I had the honour to organize the symposium at Moi University in Eldoret, Kenya, and to put together this special issue. A warm thank you also goes to Prof. Anno Mungen of the Research Institute for Music Theatre for supporting the idea, to Prof. Clarissa Vierke for all her support in enabling the symposium as well as the publication, and to the Matatu team for their tireless efforts. I would also like to thank B IGSAs for financing a major part of the symposium, my Faculty of Languages and Literatures of the University of Bayreuth for financing my own participation with a travel grant, and the VolkswagenStiftung for financing my research on talent shows as globally traded music theatre. 


\section{Works Cited}

Atome. "Ecoutez 'le son du Berger': Message de paix et identité Culturelle," at voilamoi .over-blog.com/2016/o7ecoutez-le-son-du-berger-message-de-paix-et-identite-cult urelle.html (retrieved July 26th 2018).

Aveyard, Karina, Albert Moran, Pia M. Jensen \& Toby Miller. New Patterns in Global Television Formats (Bristol: Intellect Books Ltd, 2016).

Baller, Susann. Spielfelder der Stadt. Fußball und Jugendpolitik im Senegal seit 1950 (Köln, Wien: Böhlau, 2010).

Barber, Karin. A History of African Popular Culture (Cambridge, UK and New York, NY: Cambridge University Press, 2018).

Barber, Karin. "Popular Arts in Africa," African Studies Review 30.3 (1987):1-78.

Bizas, Eleni. Learning Senegalese Sabar: Dancers and Embodiment in New York and Dakar (New York, NY: Berghahn Books, 2014).

Bradley, Sam. "Got Talent Producer Fremantle Media rebrands as Fremantle," at www .thedrum.com/news/2018/o9/o7/got-talent-producer-fremantlemedia-rebrands -fremantle (retrieved October 16th 2018).

Brunner, Anja. Die Anfänge des Mbalax: Zur Entstehung einer senegalesischen Popularmusik (Wien: Inst. Für Musikwiss., 2010).

Butler, Judith. "Performative Acts and Gender Constitution: An Essay in Phenomenology and Feminist Theory," Theatre Journal 40.4 (1988): 519-531.

Conner, Tess. “'Accept no Limitations': Expressions of Diasporic Identity in Nigerian Idol," in Idols: Authenticity, Identity and Performance in a Global Television Format, ed. Koos Zwan \& Joost de Bruin (Farnham: Ashgate, 2012): 69-8o.

Conner, Tess. "Global Reality Television and the Concept of Recursion: Idols in African Contexts," in New Patterns in Global Television Formats, ed. Karina Aveyard, Albert Moran, Pia M. Jensen \& Toby Miller (Bristol: Intellect Books Ltd, 2016): 231-244.

Ehegötz, Timmy. Internationaler Lizenzhandel mit Fernsehformaten: Die programmpolitische Relevanz des TV Formathandels für deutsche Fernsehsender; analysiert an dem Formatimport "Ich bin ein Star-holt mich hier raus!" (Hamburg: tredition, 2015).

Esser, Andrea. "European Television Programming: Exemplifying and Theorizing Glocalization in the Media," in Europe in a Global Context, European Glocalization in Global Context, ed. Roland Robertson (Basingstoke: Palgrave Macmillan 2014): 82102.

Esser, Andrea, Iain R. Smith \& Miguel A. Bernal-Merino, ed. Media across borders. Localising $T V$, film and video games (Basingstoke, New York: Routledge, Taylor \& Francis Ltd, 2016).

Farber, Alex. "ITV works with Nestlé brand on digital strategy for talent show," New Media Age (May 3rd 2007): 9 . 
Fairchild, Charles. "Building the Authentic Celebrity: The 'Idol' Phenomenon in the Attention Economy," Popular Music and Society 30.3 (2007):355-375.

Fairchild, Charles. Pop Idols and Pirates: Mechanisms of Consumption and the Global Circulation of Popular Music (Aldershot: Ashgate, 2008).

Fischer-Lichte, Erika. Performativität: Eine Einführung (Bielefeld: transcript Verlag, 2016).

Graham, Stephen. "The X Factor and reality television: beyond good and evil," Popular Music 36.1 (2017): 6-20.

Helms, Dietrich \& Thomas Phleps, ed. Keiner wird gewinnen. Populäre Musik im Wettbewerb (Bielefeld: transcript Verlag, 2005).

Kleinman, Mark. "Nestlé agrees £6m ITv Pop Idol deal," Marketing (January 3oth 2003).

Kofi Annan Foundation, "Building Stronger Economies and Communities in Africa," at www.kofiannanfoundation.org/speeches/building-communities-africa/ (retrieved October 16th 2018)

Lamarque, Matthieu. "L'Afrique a un incroyable talent-Episode 1-COMPLET," at chroniques.de.mateo.over-blog.org/2016/10/1-afrique-a-un-incroyable-talent-episo de-1-complet.html (retrieved October 16th 2018).

Lückerath, Thomas. "Fremantle feiert weltweiten 'Got Talent'-Erfolg," at www.dwdl.de/ mipcom2012/37853/fremantle_feiert_weltweiten_got_talenterfolg_/ (retrieved October 16th 2018).

Meizel, Katherine. Idolized. Music, Media, and Identity in American Idol (Bloomington: Indiana University Press, 2011).

Mieu, Baudelaire. “'L'Afrique a un incroyable talent': à Abidjan, l'émission de téléréalité recherche ses pépites francophones," at www.jeunafrique.com/328323/culture/ cote-divoire-a-abidjan-got-talent-recherche-talents-africains-francophones/ (retrieved July 26th 2018).

Music In Africa Central Africa team \& Walter Badibanga, "Le Berger-Le son du Berger," at www.musicinafrica.net/node/15729 (retrieved July 26th 2018).

Ndlela, Martin N. "Global Television Formats in Africa: Localizing Idol," in Global television formats: Understanding television across borders, ed. Tasha G. Oren \& Sharon Shahaf (Now York, NY: Routledge, 2012): 242-259.

Ndlela, Martin N. "The Political Economy of Television Formats in Africa: The Case of Big Brother and Idols," in New Patterns in Global Television Formats, ed. Karina Aveyard, Albert Moran, Pia M. Jensen \& Toby Miller (Bristol: Intellect Books Ltd, 2016): 217-23o.

Nestlé. "Africa's Got Talent and Nescafé helps talented youth to get started," at www .nestle-cwa.com/en/media/pressreleases/africas-got-talent (retrieved July 26 th 2018).

Nestlé. "L'Afrique a un incroyable talent," at www.tontalent.com/ (retrieved January 21st 2019). 
Nestlé. "Creating Shared Value Global Forum 2016," at www.nestle.com/media/media eventscalendar/allevents/creating-shared-value-forum-2016 (retrieved October 16th 2018)

Nestlé sA. Der Nestlé-Bericht zum Wassermanagement (Vervey: Nestlé, 2007).

Neveu Kringelbach, Hélène. Dance Circles: Movement, Morality and Self Fashioning in Urban Senegal (New York, NY: Berghahn Books, 2013).

Odhiambo, Christopher J. "Intervention Theatre Traditions in East Africa and the Paradox of Patronage," in Rethinking African literary and intellectual landscapes, ed. James Ogude, Grace A. Musilam \& Dina Ligaga (Trenton, NJ: Africa World Press, 2012): 55-72.

Reijnders, Stijn, Gerard Rooijakkers \& Liesbet van Zoones, "Community Spirit and Competition in Idols: Ritual Meanings of a TV Talent Quest," European Journal of Communication 22.3 (2007): 275-292.

Robertson, Roland. Europe in a Global Context, European Glocalization in Global Context (Basingstoke: Palgrave Macmillan, 2014).

Robertson, Roland. "Glokalisierung. Homogenität und Heterogenität in Raum und Zeit," in Edition zweite Moderne. Perspektiven der Weltgesellschaft, ed. Ulrich Beck (Frankfurt am Main: Suhrkamp, 1998): 192-220.

Schneller, Urs \& Res Gehriger, "Ten things you should know", at www.bottledlifefilm .com/about-the-film\#1othings (retrieved April 4th, 2020).

Sigismondi, Paolo. The Digital Glocalization of Entertainment: New Paradigms in the 21st Century Global Mediascape (New York, NY: Springer Science+Business Media LCC, 2011).

Smith, Max A. The 'Glocalization' of Mobile Telephony in West and Central Africa. Consumer Appropriation and Corporate Acculturation: A Case Study in Cameroon and Guinea-Conakry (Oxford: Langaa RPCIG, 2018).

Sūna, Laura. "Negotiating Belonging as Cultural Proximity in the Process of Adapting Global Reality Tv Formats," Media and Communication 6.3 (2018): 30-39.

Suzika et al. "L'Afrique a un incroyable talent," at fr.wikipedia.prf/w/index.php?ti tle=L\%27Afrique_a_un_incroyable_talent\&oldid $=\mathbf{1 5 3 1 1 4 7 4 3}$ (retrieved October 16 th 2018).

Tang, Patricia. African Soundscapes, Master of the Sabar: Wolof Griot Percussionists of Senegal (Philadelphia, PA: Temple University Press, 2007).

Zhang, Yuanchen. "How Culture Influences Emotion Display in Transnational Television Formats: The Case of The Voice of China," Media and Communication 6.3 (2018): $40-47$.

Zwan, Koos \& Joost de Bruin, Adapting Idols: Authenticity, Identity and Performance in a Global Television Format (Farnham: Ashgate, 2012). 